\title{
DNA LEVEL IN GUARD CELLS NUCLEI OF ORNITHOGALUM UMBELLATUM OVARY IS 2C-4C
}

\author{
Katarzyna Rogala, Maria KwiatKowsKa*, Katarzyna PopŁońsKa \\ Department of Cytophysiology, University of Łódź \\ Pilarskiego 14, 90-231 Łódź, Poland \\ * e-mail: kwiat@biol.uni.lodz.pl
}

(Received: April 17, 2007. Accepted: January 24, 2008)

\begin{abstract}
The DNA content after Feulgen reaction in the guard cells and epidermis of Ornithogalum umbellatum ovary was cytophotometrically measured in different phases of flower development. Only in bud of flowers guard cells DNA content was $2 \mathrm{C}$ while in full blown flowers it was higher, between $2 \mathrm{C}-4 \mathrm{C}$. This observation was supported by autoradiographic studies with ${ }^{3} \mathrm{H}$-thymidine which was incorporated into guard cell nuclei in the ovary epidermis of newly developed flowers. Thus DNA level in O. umbellatum guard cells was higher than those in other plants described in literature.

On the other hand, DNA content in the epidermis cells increased gradually with ovary growth reaching the maximum level of $8 \mathrm{C}$ in some cells.
\end{abstract}

KEY WORDS: Ornithogalum umbellatum ovary, guard cells, epidermis, differential DNA replication, development.

\section{INTRODUCTION}

Exit from the mitotic cell cycle and initiation of cell differentiation frequently coincide with the onset of endoreduplication, a modified cell cycle during which DNA is duplicated in the absence of mitosis. This phenomenon is especially frequent in different plant tissues (Nagl 1978; Kwiatkowska et al. 1990; Boudolf et al. 2004; Bertin 2005; Beemster et al. 2005; Verkest et al. 2005) and is especially intensive in trophic tissues (Nagl 1978). Comparative studies (Olszewska and Osiecka 1982, 1983, 1984) showed that in nearly 100 mono- and dicotyledonous plant species differentiation of root parenchyma cells was preceded by DNA endoreplication. However, there are exceptions concerning species with high 2C DNA contents. Root parenchyma cells of Tulipa kaufmaniana, Levisticum officinale, Ammaryllis belladonna, Clivia minata and Haemanthus katharinae are not endopolyploidal (Olszewska and Osiecka 1982, 1983). However, it is worth noting that in Haemanthus katharinae endosperm three endoreplication rounds were observed during seed development (Marciniak 1993).

Several authors observed that lack of DNA endoreduplication was characteristic of Arabidopsis thaliana leaf guard cells although pavement cells had endopoliploidal nuclei (Boudolf et al. 2004; Melaragno et al. 1993; Kato and Lam 2003; Bergmann 2004; Sugimoto-Shirasu and Roberts 2003; Sugimoto-Shirasu et al. 2005, Desvoyes et al. 2006). This was earlier observed in Tropaeolum majus
(Nagl 1962), because of that DNA level in guard cells was sometimes regarded as a $2 \mathrm{C}$ indicator.

Guard cells are the terminal product of lineage that arises postembryonically in the epidermis. They are epidermal structures that modulate gas exchange between a plant and its environment.

Earlier observations concerning epidermis of Ornithogalum umbellatum ovary have shown that these cells are very good material for investigations aiming at finding the answer to the question whether there is correlation between DNA content and cell growth dynamics during ovary development since at a certain moment they stop dividing and only intensively grow (Kwiatkowska et al. 2007).

We stated from the assumption that since DNA level in guard cells is $2 \mathrm{C}$ (as many authors reported) measurement of DNA content in these cells may be indicative of polyploidy level of epidermis at different developmental stages of the ovary. In order to prove this assumption comparison of the contents in the nuclei of telophase and prophase $O$. umbellatum root meristem cells with DNA content in the ovary guard cells. The guard cells of this plant do not have subsidiary cells and are of amonocite type. The obtained results show that the DNA level in the guard cells is not indicative of DNA content as during ovary development it increases reaching $2 \mathrm{C}-4 \mathrm{C}$ level which points to differential DNA replication.

It is necessary to conduct further research to find out if a similar phenomenon occurs in other plants. 


\section{MATERIAL AND METHODS}

\section{Cytophotometric analyses}

O. umbellatum root meristems were used to assess $2 \mathrm{C}$ (telophase) and 4C (prophase) DNA levels. Epidermis of the apical ovary part at different flower developmental stages was also used. The following stages were taken into consideration: 1) the ovaries hidden in buds, 2) the ovaries of fully developed flowers, 3) the ovaries of withered perianth. Small (a), median (b) and big (c) ovaries were observed at every stage. 10 ovaries were used in each experimental variant. An average number of Feulgen stained individual nuclei measured cytophotometrically was 100 and 600 for the guard cells and for epidermis cells, respectively.

For cytophotometry, ovaries were fixed in cold 3:1 absolute alcohol/glacial acetic acid mixture (Carnoy solution) for $1 \mathrm{~h}$, washed and kept in $70 \%$ ethanol. Apical fragment of root and fragments of ovary epidermis were hydrolysed $1 \mathrm{~h}$ in $4 \mathrm{~N} \mathrm{HCl}$, stained in Schiff's reagent (pararosaniline, Sigma) for $1 \mathrm{~h}$ at room temperature. After the Feulgen reaction the fragments of epidermis and squashed apical parts of roots were dehydrated, dried and embedded in Canada balsam.

Absorbance of Feulgen-stained nuclei were measured using the plug technique with Zeiss (Jena) Histophotometer. Several readings were taken at $565 \mathrm{~nm}$ to obtain an average absorbance. Profile surface areas of nuclei were measured using computerized microscope image analysis system IMAL-512.

\section{${ }^{3} \mathrm{H}$-thymidine incorporation analyses}

${ }^{3} \mathrm{H}$-thymidine incorporation analyses were carried out in the ovary epidermis of newly developed flowers in which a significant increase in DNA content in the guard cells nuclei was cytophotometrically observed.

Ovary epidermis of $O$. umbellatum were incubated in ${ }^{3} \mathrm{H}$ -thymidine $80 \mu \mathrm{Ci} / \mathrm{ml}(666 \mathrm{GBq} / \mathrm{mM})$ for $2 \mathrm{~h}$ and then fixed in Carnoy solution. The squashed preparations from epidermis were coated with liquid emulsion and exposed for 4 months. The developed autoradiographs were stained with Unna reagent (mixture of pyronine and methyl green).

\section{RESULTS}

\section{DNA content in ovary guard cell nuclei and ${ }^{3} H$-thymidine incorporation}

Comparison of the diagrams illustrating DNA contents in the telophase (2C) and prophase (4C) cells of O. umbellatum root meristem with those presenting DNA content of the guard cells from the bud ovaries showed that regardless of bud size they contained exactly 2C DNA (Fig. 1). After blooming the DNA content was significantly shifted toward 4C although no cells with full 4C were observed (Fig. 1 IIa, IIb, IIc). A similar situation was noted in bigger and bigger ovaries in withered flowers (Fig. 1 IIIa, IIIb, IIIc).

${ }^{3} \mathrm{H}$-thymidine autoradiography fully supported the cytophotometry results: over the nuclei of ovary epidermis guard cells of newly developed flowers (Fig. 3) there were dark autoradiographic grains which indicated ${ }^{3} \mathrm{H}$-thymidine incorporation hence the fact the DNA was synthesized in them at that time.

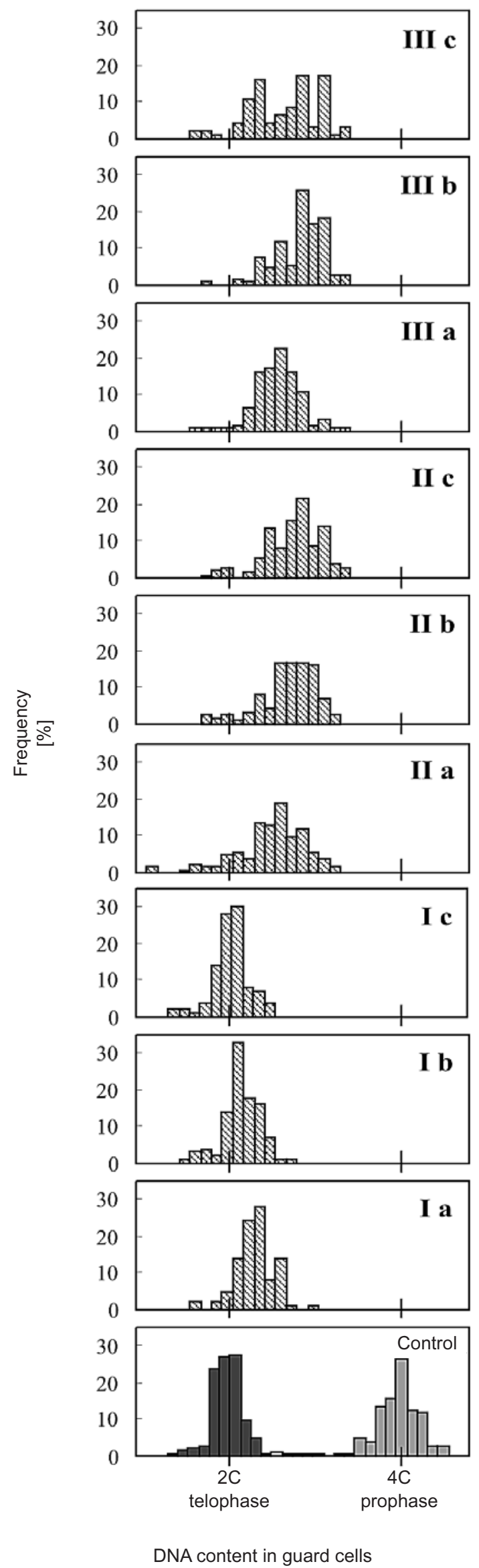

Fig. 1. DNA content in guard cell nuclei. I, II, III - closed, open and withered flowers, respectively; a, b, c-small, medium and big ovaries, respectively. Control - DNA content in telophase and prophase of root meristem of $O$. umbellatum. 


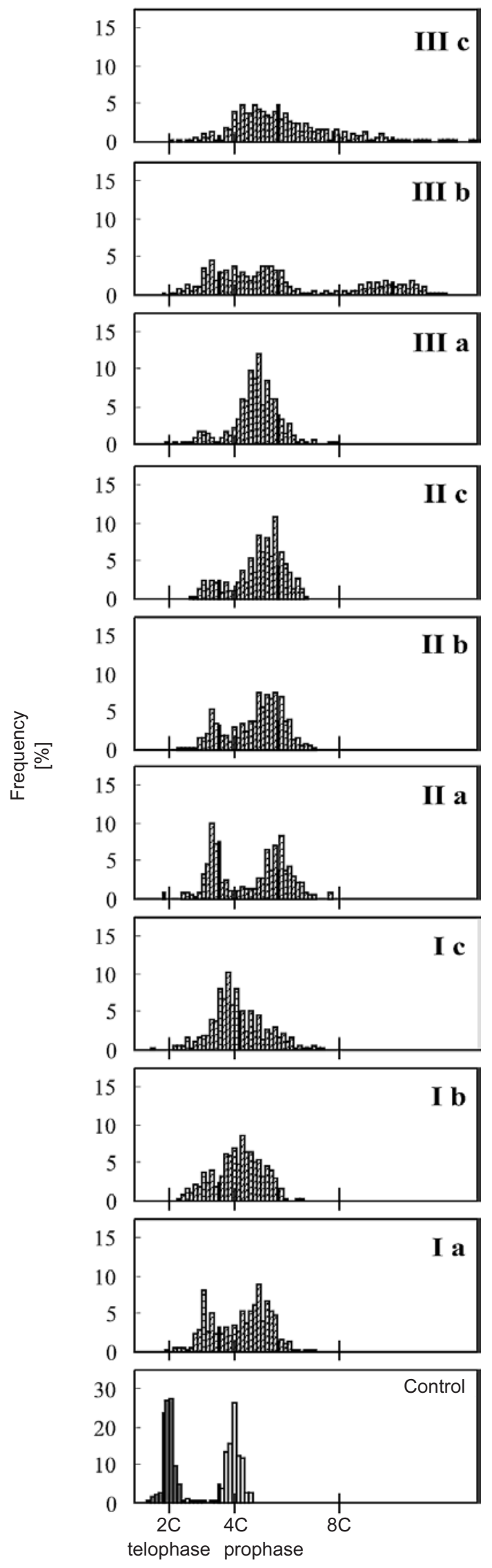

DNA content in epidermis

Fig. 2. DNA content in ovary epidermis cell nuclei; symbols as in Figure 1.

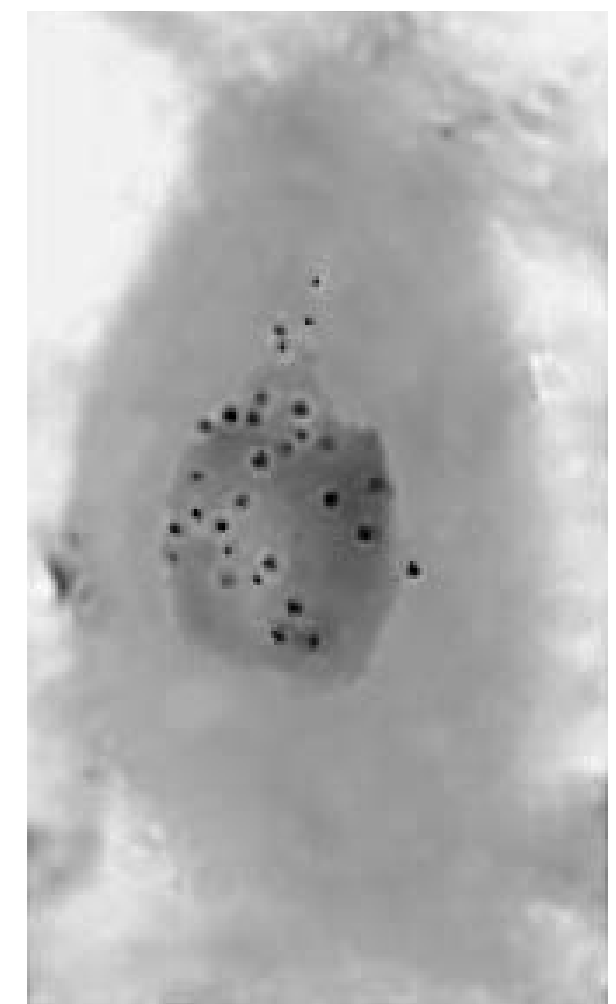

Fig. 3. Guard cells with ${ }^{3} \mathrm{H}$-thymidine labelled nuclei in the ovary of a newly open flower following Unna staining; dark grey nuclei, light grey cytoplasm.

\section{DNA content in ovary epidermis cell nuclei}

DNA content in the ovary epidermis cells was higher than $2 \mathrm{C}$ already in the youngest flower buds, and in some cells it reached 4C-8C levels (Fig. 2 Ia). Population of the latter cells increased gradually together with the ovary growth in not-blown and full-blown flowers. After withering of the perianth apart from 4C DNA nuclei a population of $8 \mathrm{C}$ DNA ones appeared in the medium-sized ovaries (Fig. 2 IIIb). In the biggest, yellowish ovaries the number of 8C DNA nuclei decreased but 4C-8C increased (Fig. 2 IIIc).

\section{DISCUSSION}

Cytophotometric measurements of DNA content in the O. umbellatum guard cells indicated differential DNA replication, according to Nagl (1978) terminology, which might be either underreplication or ampliphication of DNA. It took place when the petals opened and ovary became uncovered. The above was proved both by cytophotometric and autoradiographic methods. The same level of DNA was also observed at the later developmental stages till the ovary reached the greatest size. However, in flower buds DNA content in the ovary guard cells was exactly $2 \mathrm{C}$ thus perfectly agreed with the literature data, (Boudolf et al. 2004; Melaragno et al. 1993; Kato and Lam 2003; Sugimoto-Shirasu and Roberts 2003; Sugimoto-Shirasu et al. 2005; Desvoyes et al. 2006; Nagl 1962). The fact that differential DNA replication presented above was not described in other papers might result from the specificity of $O$. umbellatum or from the fact that it was observed on the basis of comparisons between several developmental stages of the 
organ. The fact that differential DNA replication presented above was not detected in other experiments might result from the specificity of $O$. umbellatum or from the fact that we observed it on the basis of comparisons between several developmental stages of this organ and DNA levels in telophases and prophases of meristematic cells. This kind of observations was not presented in earlier studies. Thus it is not known whether a widely recognized belief that there is no endoreplication in the guard cells in other plants is correct.

Genetic studies indicate that development and functioning of guard cells is mediated by very many genes. Apart from 1309 genes shared with other A. thaliana leaf cells there are 64 guard cell-specific genes which are responsible for both their development and functioning (Leonhardt et al. 2004). We suppose that in $O$. umbellatum guard cells differential DNA replication takes place in the genes which are triggered by light stimuli as DNA content increases above $2 \mathrm{C}$ level after opening of flowers i.e. when guard cells are exposed to light.

DNA content measurements in $O$. umbellatum ovary epidermis cells show that it gradually increases with development up to $8 \mathrm{C}$ level. Thus dynamics and the mechanism regulating DNA endoreduplication in these cells are different from those in guard cells similarly as it was observed in $A$. thaliana epidermis (Boudolf et al. 2004; Melaragno et al. 1993; Kato and Lam 2003).

Comparative studies of the dynamics of epidermis cell growth changes in DNA content accompanying them, revealed that, in the case of $O$. umbellatum, there was no simple correlation between these parameters. The role of endoreplication seems to be modified by the involvement of lipotubuloids and $\mathrm{GA}_{3}$ level in the growth of these cells.

Regardless of extensive research and of the fact that endocycles are thought to be driven by the same regulators as those that control the $\mathrm{G} 1-\mathrm{S}$ transition of the mitotic cell cycle, the molecular mechanisms that differentiate mitotically dividing cells from endoreplicating ones are largely unknown. Recently a novel class of atypical E2F-like proteins has been identified and was designated E2F7 in mammals and DP-E2F-like (DEL) in A. thaliana (Vlieghe et al. 2005; Beemster et al. 2006). Verkest et al. (2005) however, showed that the A-type cyclin - dependent kinase CDK;1 and its specific inhibitor the Kip-related protein KRP2 regulated the mitosis-to-endocycle transition during $A$. thaliana leaf development.

\section{ACKNOWLEDGMENTS}

This work was supported by University of Łódź - grant number 506/820.

\section{LITERATURE CITED}

BEEMSTER G.T.S., DE VEYLDER L., VERCRUYSSE S., WEST G., ROMBAUT D., VAN HUMMELEN P., GALICHET A., GRUISSEM W., INZÉ D., VUYLSTEKE M. 2005. Genome-wide analysis of gene expression profiles associated with cell cycle transitions in growing organs of Arabidopsis. Plant Physiol. 138: 734-743.

BEEMSTER G.T.S., VERCRUYSSE S., DE VEYLDER L., KUIPER M., INZÉ D. 2006. The Arabidopsis leaf as a model sy- stem for investigating the role of cell cycle regulation in organ growth. J. Plant Res. 119: 43-50.

BERGMANN D.C. 2004. Integrating signals in stomatal development. Curr. Opin. Plant Biol. 7: 26-32.

BERTIN N. 2005. Analysis of the tomato fruit growth response to temperature and plant fruit load in relation to cell division, cell expansion and DNA endoreduplication. Ann. Bot. 95: 439$-447$.

BOUDOLF V., VLIEGHE K., BEEMSTER G.T.S., MAGYAR Z., TORRES ACOSTA J.A., MAES S., VAN DER SCHUEREN E., INZÉ D., DE VEYLDER L. 2004. The plant-specific cyclin-dependent kinase CDKB1;1 and transcription factor E2Fa-DPa control the balance of mitotically dividing and endoreduplicating cells in Arabidopsis. Plant Cell 16: 2683-2692.

DESVOYES B., RAMIREZ-PARRA E., XIE Q., CHUA N.-H., GUTIERREZ C. 2006. Cell type-specific role of the retinoblastoma/E2F pathway during Arabidopsis leaf development. Plant Physiol. 140: 67-80.

KATO N., LAM E. 2003. Chromatin of endoreduplicated pavement cells has greater range of movement than that of diploid guard cells in Arabidopsis thaliana. J. Cell Sci. 116: 2195-2201 .

KWIATKOWSKA M., POPŁOŃSKA K., ŻYLIŃSKA K. 1990. Biological role of endoreplication in the process of spermatogenesis in Chara vulgaris L. Protoplasma 155: 176-187.

KWIATKOWSKA M., POPŁOŃSKA K., KAŹMIERCZAK A., STĘPIŃSKI D., ROGALA K., POLEWCZYK K. 2007. Role of DNA endoreduplication, lipotubuloids, and gibberelic acid in epidermal cell growth during fruit development of Ornithogalum umbellatum. J. Exp. Bot. 58: 2023-2031.

LEONHARDT N., KWAK J.M., ROBERT N., WANER D., LEONHARDT G. 2004. Microarray expression analyses of Arabidopsis guard cells and isolation of a recessive abscisic acid hypersensitive protein phosphates $2 \mathrm{C}$ mutant. Plant Cell 16: 596-615.

MARCINIAK K. 1993. DNA endoreplication level in endosperm during seed development in three monocotyledonous species. Acta Soc. Bot. Pol. 62: 143-147.

MELARAGNO J.E., MEHROTRA B., COLEMAN A.W. 1993. Relationship between endopolyploidy and cell size in epidermal tissue of Arabidopsis. Plant Cell 5: 1661-1668.

NAGL W. 1962. Über Endopolyploidie, Restitutionskernbildung und Kernstrukturen im Suspensor von Angiospermen und eiber Gymnosperme. Österr. Bot. Z. 109: 431-494.

NAGL W., 1978. Endopolyploidy and polyteny in differentiation and evolution. North-Holland Publishing Company, Amsterdam, New York, Oxford.

OLSZEWSKA M.J., OSIECKA R. 1982. The relationship between 2C DNA content, life cycle type, systematic position, and the level of DNA endoreplication in nuclei of parenchyma cells during growth and differentiation of roots in some monocotyledonous species. Biochem. Physiol. Pflanzen. 177: 319-336.

OLSZEWSKA M.J., OSIECKA R. 1983. The relationship between 2C DNA content, life cycle type, systematic position, and the dynamics of DNA endoreplication in parenchyma nuclei during growth and differentiation of roots in some dicotyledonous herbaceous species. Biochem. Physiol. Pflanzen. 178: 581-599.

OLSZEWSKA M.J., OSIECKA R. 1984. The relationship between 2C DNA content, systematic position, and the level of nuclear DNA endoreplication during differentiation of root parenchyma in some dicotyledonous shrubs and trees. Comparison with herbaceous species. Biochem. Physiol. Pflanzen. 179: 641-657.

SUGIMOTO-SHIRASU K., ROBERTS K. 2003. "Big it up": endoreduplication and cell-size control in plants. Curr. Op. Plant Biol. 6: 544-553.

SUGIMOTO-SHIRASU K., ROBERTS G.R., STACEY N.J., MCCANN M.C., MAXWELL A. 2005. RHL1 is an essential 
component of the plant DNA topoisomerase VI complex and is required for ploidy-dependent cell growth, PNAS 20: 18736-18741.

VERKEST A., DE O. MANES C-L., VERCRUYSSE S., MAES S., VAN DER SCHUEREN E., BEECKMAN T., GENSCHIK P., KUIPER M., INZÉ D., DE VEYLDER L. 2005. The cyclin-dependent kinase inhibitor KRP2 controls the onset of the endoreduplication cycle during Arabidopsis leaf development through inhibition of mitotic CDKA;1 kinase complexes. Plant Cell 17: 1723-1736.

VLIEGHE K., BOUDOLF V., BEEMSTER G.T.S., MAES S., MAGYAR Z., ATANASSOVA A., DE ALMEIDA ENGLER J., DE GROODT R., INZÉ D., DE VEYLDER L. 2005. The DP-E2F-like gene DELI controls the endocycle in Arabidopsis thaliana. Curr. Biol. 15: 59-63. 